\title{
COMMENTS
}

\section{MEDIA FILTERS, THE V-CHIP, AND THE FOUNDATIONS OF BROADCAST REGULATION}

\author{
J.M. BALKIN ${ }^{\dagger}$
}

\section{INTRODUCTION-TO V OR NOT TO V}

One of the most controversial features of the Telecommunications Act of $1996^{1}$ is its intervention in longstanding disputes about violence and mdecency nit the media. Due in part to the urging of President Clinton and his Democratic allies, the new Act requires that all television sets over thirteen inches include a " $\mathrm{V}$ chip," a device that would allow parents to block violent and indecent television programming. ${ }^{2}$

Despite its name, the V-chip is not a single chip at all, but a combination of different teclinologies. All television programs currently have the capacity to carry extra information-like closed captioning-as well as sound and pictures. An electronic circuit in a television or cable box can be designed to block programs by reading a numerical code broadcast along the same band used for closed captioning. Viewers then use a remote control device to select froin a menu of choices as to how much violence, bad language, sex, and nudity they wish to tolerate. A rating system now being tested in Canada features a five-number scale, with higher numbers signifying noore sex and violence. When the V-chip circuitry reads a rating equal to or higher than the consunier's preselected number, the picture is replaced by a large black box. ${ }^{3}$

$\dagger$ Lafayette S. Foster Professor, Yale Law School. My thanks to Owen Fiss and Scot Powe for their comments on a previous draft, and to Michael Adler for his research assistance.

1. Pub. L. No. 104-104, 110 Stat. 56 (1996) (to be codified in scattered sections of 47 U.S.C.).

2. $\S 551,110$ Stat. at $139-42$. As its name implies, the V-chip technology has been touted primarily as a means of controlling television violence. But its uses are not limited to that category. The Telecommunications Act of 1996 specifically lists its coucerns as "sexual, violent, or other indecent inaterial." § 551(b)(1), 110 Stat. at 140.

3. Joseph A. Kirby, Device Would Let Parents Program TV for Children, TIMESPICAYUNE (New Orleans), Jan. 7, 1996, at A26. The V-chip can also be designed to 
Critics charge that the V-chip raises serious First Amendment problems. This essay explores a few of them. But my more important goal is to use the debate over the V-chip to rethink the foundations of broadcast regulation. The federal courts, including the Supreme Court, have justified content-based restrictions on broadcast indecency partly on the grounds of the special nature of the mass media. Yet their justifications for special treatment have been, on the whole, unconvincing. I will argue that the real issues have hittle to do with traditional justifications of scarcity, public interest, and pervasiveness. They have to do with how different media permit the filtering of information. Different communication technologies are better adapted to different kinds of informational filters. For example, broadcast media permit different and more limited filters than print media. The V-chip promises to change all that by creating a new system for filtering broadcast information. But this new technology raises many new and unexpected problems. In particular, it raises the possibility that in the Information Age, control of filters may be one of the most important forms of power over human thought and human expression. In the Inforination Age, the informational filter, not information itself, is king.

\section{The DifFerence Broadcasting MaKes}

For many years, broadcast media have been subject to much greater content-based regulation than print media. For example, in FCC v. Pacifica Foundation, the Supreme Court upheld the constitutionality of FCC restrictions on indecency as apphied to a radio broadcast of George Carhin's "Filthy Words" monologue. ${ }^{4}$ More recently, the D.C. Circuit upheld "safe harbor" provisions that permit indecent speech on broadcast television ouly from 10 p.m. to 6 a.m..$^{5}$

recall previous settings and block all unrated programs. Id. In order to prevent bad language from being transmitted, it must be able to block sound as well.

4. 438 U.S. 726 (1978), reh'g denied, 439 U.S. 883 (1978).

5. Action for Children's Television v. FCC (ACT III), 58 F.3d 654 (D.C. Cir. 1995) (en banc), cert. denied, $116 \mathrm{~S}$. Ct. 701 (1996). The relevant law actually permitted stations to broadcast indecent programming from midmight to 6 a.m., but it also permitted public television stations that go off the air before midnight to broadcast the same programming starting at 10 p.un. Public Telecommunications Act of 1992, Pub. L. No. 102-356, $\$ 16(a)$, 106 Stat. 949, 954 (codified at 47 U.S.C. \$ 303 note (Supp. V 1993) (Broadcasting of Indecent Programming; FCC Regulations). Because the court found the exception for public broadcasting to undermine the purposes of the legislation, it renuanded the case to the FCC with instructions to limit the ban on indecent programming to the period from 
First Amendment scholars are divided as to whether this special treatment is constitutional. They have good reason to be concerned. "Indecency," like violence, is an unclear and wavering category. By definition, it includes sexually exphicit speech that could not be regulated as obscene. This is a nuch larger category than many people imagime. It includes, for example, not only expression expressly designed for sexual stimulation, but also expression that is offensive to some but not obscene because it has genuine literary, artistic, political or scientific value. Thus, mdecent expression can include not only the more salacious contents of the Playboy Channel, but also pohtical speeches laced with four-letter words and serious discussions of AIDS and lomosexuahty.

Similar problems honnd the regulation of violence. ${ }^{6}$ It is not always clear what kinds of violence do the most harm to children. Is the violence in cartoons worse than the violence in live action programs? Does unrealistic violence do more liarm than depictions that bring home the liorrors of war and death? Does the violence reported on the local and national news contribute to the problem, and if so, should it also be restricted in the interests of our children?

In assessing the constitutionality of restrictions on violence and indecency, it is inportant to remember that the programming at issue here would be constitutionally protected if it appeared im print media, in a movie theater, or on a videocassette. There must be some special justification for abandouing general First Amendment principles in broadcast regulation.

Traditionally, content-based regulations of the broadcast media have been justified on two basic grounds: the scarcity of the airwaves and the pervasiveness of the medium. Other explanations-the fact that broadcasters hold licenses from the government, and the importance of einpowering democracy-tend to be parasitic on the scarcity rationale. Unfortunately, each of these justifications becomes problematic when applied to questions of violence and indecency.

The most common argument for special content-based regulations of the media is based on the scarcity of the airwaves. The word "scarcity" is poorly cliosen. All valuable resources are scarce.

6 a.m. to 10 p.m. $A C T$ III, 58 F.3d at 669-670.

6. For an accessible (and skeptical) view, see THOMAS G. KRATTENMAKER \& LUCAS A. POWE, JR., REGULATING BROADCAST PROGRAMMING 120-34 (1994). 
The scarcity problein in broadcasting stems from the fact that no two broadcasters can use the same frequency at the same time in the same geographical area, or they will block each other out. ${ }^{7}$ But this problem can be dealt with by creating a system of property rights dividing up the airwaves according to frequency, time, place, and broadcasting power; it does not require a system of government hicenses. ${ }^{8}$ Moreover, the existing systein has actually created an artificial scarcity in broadcast television. Many VHF and UHF channels go unused in many localities.'

The spread of cable television has increasingly made the scarcity arguinent implausible. More than half of all American homes now receive cable, ${ }^{10}$ and cable television wiring passes by most of the rest. ${ }^{11}$ If the government is really interested in reducing scarcity and increasing choices, it should simply subsidize cheap cable television for the reinaining households instead of artificially limiting access through the award of broadcasting licenses.

In any case, scarcity is a particularly badly suited justification for content-based regulation of violence and indecency. At best, scarcity provides a reason to put things on the air, not to keep things off. Because airtime is limited, governments may require that stations broadcast certain kinds of public interest programming, like local news or children's programming; it inay also require that candidates for public office have the opportunity to pur-

7. See Turner Broadcasting Sys. v. FCC, 114 S. Ct. 2445, 2456 (1994) (citing National Broadcasting Co. v. United States, 319 U.S. 190, 212 (1943)), reh'g denied, 115 S. Ct. 30 (1994).

8. Critiques of the scarcity rationale are by now legion. For a sampling, see LuCAs A. POWE, JR., AMERICAN BROADCASTING AND THE FIRST AMENDMENT 197-209 (1987); MATTHEW L. SPITZER, SEVEN DIRTY WORDS AND Six OTHER STORIES 1013-20 (1986); Ronald H. Coase, The Federal Communications Commission, J.L. \& ECON., Oct. 1959, at 1, 12-27.

9. See KRATTENMAKER \& POWE, supra note 6 , at $87-88,217-18$ (discussing the FCC's restrictive channel allocation pohicies).

10. See H.R. CONF. REP. No. 862, 102d Cong., 2d Sess. 56 (1992) (stating that nearly 56 million households and more than $60 \%$ of all households with televisions are cable subscribers); Robert S. Tanner, Note, The Data Transfer Industry: Communications Regulation for the Next Century, 17 HASTINGS COMM. \& ENT. L.J. 917, 922-23 (1995) (citing Chesapeake \& Potomac Tel. Co. v. Umited States, 830 F. Supp. 909, 915 (E.D. Va. 1993)).

11. Leland L. Johnson, Toward Competmion IN Cable Television 179 (1992) ("[C]able systems have beconie accessible to nuore than 95 percent of the nation's homes."); see also US West, Inc. v. Umited States, 855 F. Supp. 1184, 1192 (W.D. Wash. 1994) ("[C]able service is now available . . a at $96 \%$ of all U.S. homes . . ."), affd, 48 F.3d 1092 (9th Cir. 1994), cert. granted and judgment vacated, 116 S. Ct. 1037 (1996). 
chase airtime and respond to personal attacks. But limited resources do not justify keeping particular programming off the air if there is otherwise sufficient room for it. To be sure, requiring that some things be on the air will necessarily require broadcasters to leave other things off. But the scarcity rationale does not by itself give the government any right to choose what that forgone programming will be, unless it thinks that scarcity entitles it to dictate the whole of the broadcaster's day. The justification for keeping indecency off the air cannot be to make room for the presidential debates; it must he elsewhere.

Many other justifications for regulation of violence or indecency often tend to be parasitic on the scarcity rationale. For example, in Red Lion Broadcasting Co. v. FCC, ${ }^{12}$ the Supreme Court suggested that content-based regulation was permissible because broadcasters do not own the airwaves outright. ${ }^{13}$ They hold licenses from the government, and therefore the government can impose conditions on that hicense. By itself, this argument tends to prove too mucli. The government's conditions may be unconstitutional conditions. The government does not license the airwaves as an act of governmental largesse-the usual means of justifying conditions on licenses. ${ }^{14}$ Rather, the licensing scheme exists because the government decided to take complete control of the airwaves and parcel out licenses instead of auctioning off rights to broadcast at certain times im certaim locations and with certain degrees of broadcast strength. The government does not hicense the manufacture and distribution of paper or printing presses. Even if it did so, it could not constitutionally justify imposing content-based conditions on their use. Thus, the conditionson-licensing justification ultimately rests on the prior justifications for licensing, which depend in turn upon the scarcity rationale.

FCC Chairman Reed Hundt has suggested that restrictions on violence and indecency on television may be justified by the fact that the First Amendment is designed to protect democracy. ${ }^{15} \mathrm{He}$

12. 395 U.S. 367 (1969).

13. Id. at 394 .

14. See, e.g., Rust v. Sullivan, 500 U.S. 173, 199 n.5 (1991) (stating that restrictions on abortion counseling by recipients of Title $X$ subsidies do not violate the First Amendment because the subsidy may be declined); Regan $v$. Taxation with Representation, 461 U.S. 540, 545 (1983) (holding that the ban on lobbying activity by tax-exempt charitable organizations is not an unconstitutional condition).

15. Reed E. Hundt, The Public's Airwaves: What Does the Public Interest Require of 
argues that violent and indecent programs were not what James Madison had in mind when he wrote the First Amendment; ${ }^{16}$ they do nothing to proinote discussion of public issues. This seems to conflate an argument that some speech is of lesser constitutional value with an argument that the broadcast media are special. Assuming that Chairman Hundt's claim about degrees of constitutional value is sound, it applies equally well to violent and indecent depictions in movies and the print media. It caumot by itself distinguislı broadcast media from other media. ${ }^{17}$ In any case, the argument tends to prove too mucli: A great deal of non-indecent and nonviolent programming on television has only the famtest relationship to promoting deinocracy. Yet it does not follow that this programming is subject to content-based regulation because it is also of low constitutional value.

In fact, the argument from democracy is best viewed as an adjunct to the scarcity argument. Because airtime is scarce, television must make rooln for programming that enhances democratic values. But agam, this argument does not justify keeping indecency or violence off the air; rather, it justifies keeping public interest programming on.

The other inajor justification usually offered for special treatinent of the broadcast inedia is that these media are uniquely "pervasive." Like the term "scarcity," the term "pervasiveness" is also badly chosen. In fact, courts seein to use the term "pervasive" to stand for a conglomeration of five different sorts of justifications about broadcasting, often not fully distinguished. The broadcast inedia are pervasive first, because they are the most powerful medium of communication, and second, because they are ubiquitous. Yet the fact that a mode of cominunication is particularly powerful or ubiquitous is not necessarily a reason for regulating it. That would suggest that the only speecli that escapes regulation is that which doesn't do its job very well.

Television Broadcasters?, 45 Duke L.J. 1089, 1097 (1996).

16. See id. at 1126.

17. In any case, it is an opportunistic invocation of original intention. Chairman Hundt is surely not suggesting that we hew to the original intentions of the Framers in all areas of free speech law. They were clearly more censorions than he would be comfortable with. The best version of his argument is Meiklejohn's. See generally ALEXAN-

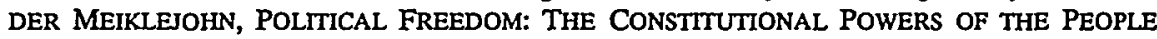
(1961). But Meiklejohn's argument has its own difficulties. I rehearse some of them in J.M. Balkin, Populism and Progressivism as Constitutional Categories, 104 YALE L.J. 1935 (1994). 
A third interpretation is that television is "pervasive" because it is constitutive of our culture. We now live in a television culture, in which an increasing number of our cultural allusions are drawn froin television. If we are what we eat, then perhaps we are also what we watch. Hence, many people secretly and not so secretly worry that whoever controls television controls culture, and they want to make sure that our culture is not thereby debased. But when the matter is put so starkly, the desire to use government to control culture by controlling what people watch on television cannot be a constitutional justification for the regulation of free expression.

A fourth meaning of "pervasiveness" is a restatement of the captive audience doctrine. Television is "pervasive" in the sense that there are significant cultural pressures to have a television set and keep it in one's home. Once television is in the home, it is difficult to protect unwilling histeners from encountering programs they don't want to watch other than by keeping the television turned off at all times. The captive audience doctrine, it is said, has special force in the home because expectations of privacy are higher there. ${ }^{18}$ Although television can be watched outside of the home-in a sports bar, for example-the fact that the overwhelming majority of Americans watcl it at hoine is said to justify content-based regulation that would be impermissible if applied to the print inedia. However, when applied to adults, the captive audience rationale tends to prove too much. One can also accidentally come across printed material in the hoine. A newspaper or magazine might have offensive language buried on page fifteen; a videocassette might have offensive language or pictures in a "comimg attractions" segment. But the fact that such a "sneak attack" might occur in the lome does not justify content-based regulation of print media or videocassettes.

The fifth and final interpretation of "pervasive" is, to my mind, the inost miportant, and the only one that really justifies special content-based regulation for the broadcast media. It is a concern about parental control of children's viewing habits. ${ }^{19}$ Television is pervasive because it is difficult to keep it away from children and children away from it. Once television is in the

18. FCC v. Pacifica Found., 438 U.S. 726, 748-49 (1978), reh'g denied, 439 U.S. 883 (1978).

19. Id. at 749; ACT III, 58 F.3d at 661 . 
hoine, parents must continually supervise what children watch, which is difficult and time-consuming. Many households now own multiple television sets, so that children can watch in the privacy of their own room, away from parental supervision. It is always possible for parents to remove television completely from the home. However, because of television's cultural importance, many parents do not feel able or willing to deny their children the right to watch television at home, especially when the children can watch it at their friends' houses.

Although concerns about children make the most sense doctrinally, it's important to reiterate that they have little to do with scarcity. Even if there were 500 channels, the problem of parental supervision would still exist, and might even be enhanced. Nor does this justification for regulation turn on the fact that broadcast television is an especially powerful medium of communication, or that it is conveyed in the easily assimilable forn of pictures. Parents can watch rented movies on a VCR that are every bit as unacceptable for children as anything one might watch on television. But these movies cannot be regulated in the saine way that television broadcasting can. ${ }^{20}$

This final rationale for broadcast regulation is often described as the protection of children, but the real issue is parental control. The two are not necessarily the saine. We generally assume that parents love their children and discipline them in ways that are, on the whole, best for them. But parents do not always do so, and we do not second-guess their decisions except in extreme cases. Parents are currently free to bring home R-rated videos full of violence and nudity and let their children watch them. They can subscribe to premium cable chamels showing these movies and leave their cable lock boxes unused. If violence and indecency really are bad for children, and we think protection of children is paramount, we should take steps to criminalize such behavior, whether or not parents misguidedly beheve such exposure is harmless. Yet I suspect that such proposals would be severely

20. With a few exceptions-zoning regulations for adult movie theaters and procedures for pre-screening obscene films-the regulation of movies is largely along the lines of the print model. See, e.g., City of Renton v. Playtime Theatres, 475 U.S. 41 (1986) (upholding zoning requirements for adult movie theaters), reh'g denied, 475 U.S. 1132 (1986); Young v. American Mini Theatres, 427 U.S. 50 (1976) (same), reh'g denied, 429 U.S. 873 (1976); Freedman v. Maryland, 380 U.S. 51 (1965) (establishing procedures for reviewing obscene films). 
criticized, and not merely by civil libertarians. Most parents do not want the government deciding what is best for their children when the decisions are contrary to their wishes; they want the government to assist them in controlling their children in ways they think appropriate. ${ }^{21}$

In short, behind the slogans of "scarcity" and "pervasiveness" lurks the real issue of parental control. This explains, I think, how current calls for media regulation are tied to the underlying anxieties of the moment. Calls for censorship (which exist at all times) arise most heatedly in moments of great cultural change and uncertainty. After all, where cultural mores are relatively stable, censorship can be achieved informally and without the constraimts of law. But we now live in a time of cultural upheaval, caused by significant economic and technological changes as well as changes in mores. Not surprisingly, many people are especially anxious about these changes; they see the world they once knew shpping away. Like the drunk who searches for his keys near the lamppost because the light is better there, people tend to fix upon the mass media as the likely cause of cultural ills and regulation of the mass media as a likely solution.

The First Amendment prohibits relatively direct control over what adults can be exposed to. Hence the focus naturally turns to control of children, who are under their parents' authority and whom parents see as the natural inheritors and perpetuators of their cultural values. The desire to preserve culture in the face of widespread cultural change (and, in particular, economic and technological change) leads to anxieties over children and the desire to reassert parental control over them.

The problem we face today, however, is that new forms of technology imcreasingly upset estabhished patterns of parental control. Children can operate VCRs and computers better than their

21. The D.C. Circuit recognized that parental control and protection of children were separate interests, but it did not acknowledge the degree to which they might conflict in practice. ACT III, $58 \mathrm{~F} .3 \mathrm{~d}$ at 660-61. In fact, safe harbor rules do not perfectly mesh with the goals of enhancing parental control. As Chief Judge Harry Edwards pointed out in his dissents in Alliance for Community Media and ACT III, safe harbor rules actually preempt some parental choice, because children cannot watch certain programming (for example, a documentary on AIDS prevention) even if parents want them to. Alliance for Community Media v. FCC, 56 F.3d 105, 145-46 (D.C. Cir.) (en banc) (Edwards, C.J., dissenting), cert. granted, 116 S. Ct. 471 (1995); ACT III, 58 F.3d at 670 (Edwards, C.J., dissenting). 
parents. They spend more time in front of the television than at the family dinner table. Technology threatens to render parents' means of cultural reproduction imeffectual. It is no wonder, then, that new forms of communication technology, whether they be movies, records, radio, television, or the Internet, produce new cultural anxieties and new calls for censorship and control.

Courts are not insensitive to these cultural and political pressures. When these pressures are combined with the complexities of the dual regime of broadcast and cable regulation, it is no wonder that the current scheine of indecency regulation is both confusing and contradictory, and that doctrinal treatments tend to display gaps and deficiencies. Two recent D.C. Circuit cases slow that court's fitful attempts to deal with the problems. In Action for Children's Television v. FCC (ACT III), ${ }^{22}$ the D.C. Circuit upheld the "safe harbor" provisions of Section 16(a) of the Public Telecommnnications Act of 1992, which permit indecent broadcasts between 10 p.In. and 6 a.m. In Alliance for Community Media v. $F C C{ }^{23}$ the D.C. Circuit upleeld Section 10(b) of the 1992 Cable Television Consunier Protection and Competition Act. ${ }^{24}$ That provision requires cable television operators who carry indecent programming on leased access channels to segregate the programming on a single channel or group of cliannels and to block access unless a subscriber requests it in writing. The Supreme Court has granted certiorari in this case.

Although the D.C. Circuit justified the safe harbor rules in $A C T I I I$ as a narrowly tailored means of protecting children, its justification was undercut by the fact that Section 16(a) did not apply at all to cable television, giving children ample alternative sources of dissolution and corruption. ${ }^{25}$ Perliaps in response to this deficiency, the D.C. Circuit extended the pervasiveness rationale of Pacifica to cable television in Alliance for Community Media. The court reasoned that because cable television provides inore than $60 \%$ of all houseliolds with television, it has beconie the dominant inode of video delivery. Moreover, "[a] cable subscriber no inore asks for such programming than did the offended

22. 58 F.3d 654 (D.C. Cir. 1995), cert. denied, 116 S. Ct. 701 (1996).

23. 56 F.3d 105, 145-46 (D.C. Cir.) (en banc), cert. granted, 116 S. Ct 471 (1995).

24. Pub. L. No. $102-385$, \& 10(b), 106 Stat. 1460,1486 (codified at 47 U.S.C. \& 532 (j)) (Supp. V 1993).

25. See ACT III, $58 \mathrm{F.3d}$ at 672 (Edwards, C.J., dissenting). 
histener in Pacifica who turned on his radio,"26 and cable is just as accessible to children as broadcast programming.

One might criticize Alliance for Community Media on the grounds that cable is different from broadcast television, relying on the Supreme Court's recent opinion in Turner Broadcasting System, Inc. v. FCC. ${ }^{27}$ But the reasons why the Court differentiated cable from broadcast television were just variations on the old scarcity rationale. Because there are lots of cable channels, the scarcity justification doesn't apply. ${ }^{28}$ In fact, given the existence of cable, the scarcity justification probably shouldn't apply to the broadcast media either, but that is beside the point. What is important is that the scarcity rationale is separate froin concerns about parental control, and in the latter respect cable is largely indistinguishable from broadcast television.

Nevertheless, the D.C. Circuit was not completely consistent in its application of this rationale. It argued that the safe harbor provisions apphicable to broadcast television would not be an adequate way of protectimg children from indecency in cable television: "Even during late hours, some unsupervised children will be watching cable television and thereby have access to indecent programming."${ }^{, 29}$ However, this is equally true of broadcast television. Thus, one wonders, if safe larbor provisions were thought adequate to protect children from indecent broadcast programming, why are they inadequate for cable $?^{30}$ Indeed, if the rationale of $A C T I I I$ is correct, why isn't the constitutionally preferred solution to block mdecent programming on cable only between 6 a.m. and 10 p.m. (unless the consumer requests otherwise in writing), but require no blocking during the safe harbor period?

\section{Thinking about Media In Terms of FILTERS}

It miglit be best to start over again and think about where the real differences between broadcast and other media lie. I believe that the answer to this question must begin with features that all commumications media share in common. All media, I

26. Alliance for Community Media, 56 F.3d at 124.

27. 114 S. Ct. 2445 (1994), reh'g denied, 115 S. Ct. 30 (1994).

28. Id. at 2456-57.

29. Alliance for Community Media, 56 F.3d at 125.

30. Especially since the D.C. Circuit assumed that constitutional scrutiny would be lower for content-based regulation of broadcast media. ACT III, 58 F.3d at 660 . 
shall argue, whether voice, print, or broadcast, share two features in differing degrees. The first is the ability of the recipient to exclude infornation; the second is the presence or absence of filtering mechanisms. Filtering and excludability are related to each other, because filtering information usually depends on the present or potential ability to exclude it. ${ }^{31}$

Print inedia lend themselves easily to filtering precisely because print inedia are easy to exclude. If I want to avoid the information contained in a newspaper, I can simply avoid buying it. If I go into a bookstore, I can buy the book I want without buying other books. I can take the books I want hoine and then lock thein up so that iny children cannot see them. Print inedia are also easy to select and organize. Because iny books are discrete units, I can organize them alphabetically. I can read thein when I want and in the order I want.

Filtering inechanisms fall into three basic types or functions-they can organize information (for example, by classifying it), they can select information, or they can block information. Within the last category, one can block infornation for one's self or for others (for example, one's children). All of these functions have important relationships to excludability. Blocking information clearly involves exclusion, but so do selection and organization. To select information, I must be able to take it and not other inforination. To organize inforination, I must be able to create categories into which that information (and not other information) falls, and through which that information could (in theory) be selected. ${ }^{32}$

31. When we think of excludability, we think of captive audiences, and when we think of captive audiences, we think of justified expectations of privacy. Although excludability and privacy are related concepts, they are related in complicated ways. Practical excludability does not by itself determine whether we have a justified expectation of privacy. On the one hand, expectations of privacy seem to be based in part on the practical possibility of exclusion. Because one can be assaulted by billboards or by voices in the street, one's justified expectations of privacy are lower there. On the other hand, expectations of privacy are sometimes thought justifiable whether or not excludability is practically possible. Even though we may not be able to prevent electronic eavesdropping, we have a justified expectation that others will not eavesdrop.

32. Thus, in alphabetizing a list, I make selection by first letters possible. Placing books in the Library of Congress cataloguing system enables readers to find books on some subjects without having to look at others.

Some forms of organization have a more attenuated relationship to excludability. Suppose I merely imagine a system for cataloguing hbrary books. Although this systein organizes information, the organization is not implemented. The imaginary system merely 
Although I have divided up filters into blocking filters, selecting filters, and organizing filters, these functions substantially overlap. The V-chip is a good example. The V-chip is a blocking filter for children, but it also is a selecting filter for their parents. It lets adults choose whether or not to view violent or indecent inaterial. Equally importantly, the V-chip is an organizing filter, because it creates two types of programming-programming that is blocked by the V-chip and programming that is not. Or, if the V-chip has multiple settings, it creates inultiple categories of programming.

Installing an informational filter simultaneously raises and lowers pre-existing costs of searching for, blocking and receiving information. A V-chip raises costs of receiving information substantially to children, and moderately to adults. But it also lowers costs as well, because it subdivides the body of programming and makes certain types of choices easier.

Throughout this article I shall speak in terms of "informational" filters. Nevertheless, becanse of its computer-age connotations, the term "information" is likely to be understood much too narrowly. Many people associate information with statements of fact, or with strings of ones and zeros that can be read by a computer. Yet inuch of what people want to and do filter out is not information in that limited sense. They want to filter out dirty language, violence, and nudity. They also want to filter out dangerous ideas and views they do not agree with or expressions that offend and anger them. "Information," in the broader sense I ain concerned with, is cultural information. It does not consist merely of statements of fact, but mcludes anything that can be understood by someone in a culture, and have a corresponding effect on their reason, emotions, or behavior. Cultural information is the counterpart of cultural understanding. Hence it is involved im not only the production of knowledge or ignorance, but also persuasion or offense, refinement or coarsening, ennoblement or corruption.

Because there is too much information in the world, all coinmunications inedia produce attempts at filtering by their audiences. ${ }^{33}$ The desire to filter is not, however, always matched by

gives directions for implementation, which if enacted, would require selection, and hence the possibility of exclusion. Finally, purely mental organization of information does not involve physical selection and exclusion, but it does involve mental selection and exclusion.

33. The desire by producers of information to gam an audience and the contrary 
available methods of filtering. Each medium offers different means of exclusion, and different costs of exclusion. Filtering is an effective strategy precisely to the extent that excludability is possible and cost-effective. Each medium's abihty to permit exclusion determines and limits the kinds of filtering that are available to it. Even when filtering is used to organize infornation or facilitate selection, it is still limited by the possibilities of exclusion characteristic of the medium.

An example from the print media may illustrate this point. Suppose that Time magazine started publishing lots of four-letter words and sexually suggestive pictures. Eventually Time magazine would get a reputation as the sort of magazine that does that sort of thing. Parents would, after a time, discover this. Some of them would cancel their subscriptions to Time magazine; others would not keep it lying around the house. Advertisers would also notice the change. They would discover that the demographics of the readership had changed and would shift their money accordingly. A magazine's reputation can act as a kind of filtering device, although it is social rather than technological. It signals the likely content of the magazime. Many filters work by offering signals to the audience. Examples are titles of books and headers in the dehivery of e-mail. Nevertheless, Time's new reputation would lave hittle practical effect as a filtering device unless parents could exclude it by refusing to buy it or by not bringing it into their homes. If they could not act on Time magazine's new reputation by excluding it, the use of reputation as an informational filter would do hittle good, other than perhaps to warn parents to discount what they read in the magazine (which is itself a filter of a different sort). ${ }^{34}$

desire by recipients to block out unwanted information creates an arms race between filters and ways of getting around filters; hence the use of flashier graphics, louder music, and increasingly hyperbohic claims to attract people and gain a shice of their increasingly valuable and limited attention spans. Audiences use remote controls to flip through channels during commercials; advertisers respond by varying the content, length, and timing of their advertiseinents, and broadcasters respond by varying the length of time between shows. Marcia Mogelonsky, Coping With Channel Surfers, AM. DEMOGRAPHICs, Dec. 1995, at 13. Occasionally methods of filtering and inethods of evading filters start to nerge. For example, best seller lists are both means for weeding out books that might be interesting to read and means by which publishers promote books as worth reading. Kudos on the backs of books also have this dual character.

34. This example also suggests that filtering is a heuristic device for dealing with information, and as a heuristic device, it is usually unprecise. For example, I may use Time magazine's new reputation as a reason not to bring it into my home. There may 


\section{FILTERING AND CHOICE}

At first glance, filtering seems to overlap with a much more familiar concept-choice. But the two ideas are distinct in important ways. Not all informational filtering involves conscious or deliberate choice by an audience. Indeed, the importance of filters consists precisely in the ways that they obviate or skew choice even as they enable it. "Clooice" is a word with largely positive connotations of personal responsibility, respect for individual intelligence and protection of personal autonomy. Filtering, on the other liand, is morally ambiguous; it may inake little demands on individual intelligence, may involve considerable surrender of personal responsibility and may actually undermine personal autonomy. Filtering, especially in the Information Age, mcreasingly imvolves delegation of choice to another party. Thus, it is very important not to collapse filtering into clioice, thereby absorbing the latter's positive moral connotations.

Let me give an example drawn from my own experience as a legal acadenric. Currently there is more hterature being published in law and related acadennic fields than any person can possibly keep up with. Hence I and many other legal academics make use of filters. One is a periodicals list. Another is searching on databases like LEXIS and Westlaw. The periodicals list gives ine the titles of articles in different law reviews. This filter is widely distributed in identical form to many acadenrics; I do not receive a version tailored to my specific needs. By contrast, an informational filter like a LEXIS or Westlaw database is partially modifiable by the use of search terms.

Both the periodicals list and the computer databases already filter out publications even before they offer ine possibilities for choice. For example, I do not liave a clioice about what law-related journals to include or exclude. In LEXIS and Westlaw databases, I am limited to the journals that are currently on-line and the databases' selected periods of coverage. They will show me nothing pubhished before 1982, for example. Recently a fellow law professor wrote me asking for a cite to an article I wrote in 1990. She could not find the article on LEXIS because the article was

be lots of things in the new Time nnagazine that are just like the old Time magazine-useful news stories, for example. But the overall reputation, and not the precise content of the stories, will determine whether parents subscribe and what kinds of advertising revenues the inagazine generates. 
publisled in Cardozo Law Review and LEXIS' coverage of that review begins in 1994. Any articles written before that time do not appear on the database. My colleague depended heavily on LEXIS because it was easy to use; looking outside of it took considerable effort.

The LEXIS database has an interesting effect on the cost of obtaining and filtering information. It lowers the costs of searching for materials if one uses the database, while the costs of more traditional hard-copy searclies remain constant, at least in the short run. ${ }^{35}$ Furtherinore, if one shifts to LEXIS as a primary research tool, certain types of filtering choices (i.e., searches) become easier and less expensive to make than others, even if the latter clioices would be easier or less expensive using a different filtering system. ${ }^{36}$

This example demonstrates one of the important side effects of inforinational filters. If everyone uses LEXIS to do basic legal research, articles that do not meet LEXIS' selection criteria will mcreasingly disappear from view, because the filter changes the differential costs of searching for and receiving certain kmds of infornation. And this example suggests a larger poimt. The structure and content of public communication can be and often is shaped by the informational filters people most commonly use and depend on.

I use filters like the periodicals hist and LEXIS and Westlaw because they liave definite advantages. I do exercise clroice in using them. Yet iny clioice is at the same time limited. In using a particular filter, I have delegated clioice to some otler entity-in this case, the people who put together the periodicals list, and the people who run LEXIS and Westlaw. I lope that they know what they are doing, and that, over time, they will mclude most of the journals I might want to read. But they might not, and, as a result, ny clioices may be limited or skewed without my even knowing it.

Literary critics liave always known about filters. They call them canons and antlologies. Canons and antloologies are special

35. In fact, the costs of more traditional searches might even increase in the long run if older skills and sources atrophy as a result of mass shifts to LEXIS and Westlaw.

36. Law librarians have long understood that the shift to computer databases alters the way legal research is conducted. See, e.g., JAMES A. SPROWL, A MaNual For COMPUIER-ASSISTED LEGAL RESEARCH 14-15 (1976). 
kinds of filters that involve special forms of delegation. People who construct canons and anthologies decide what is important to read, and, by implication, what is less important to read. Canons and anthologies can be very helpful filters. They introduce people to the works inost worth reading or most often discussed in the academic hiterature. In this way they can enable not only choice, but also the search for truth. But as repeated debates over canonicity have shown, canons and anthologies can also skew or inhibit these values.

More generally, the inarketplace produces any number of informational filters. Book publishers screen manuscripts to determine which ones are most likely to be worth reading. Bookstores stock, classify, and sell books by category and likely readership interest. Magazines specialize in particular kinds of stories and particular political approaclies, and the public can use their reputations as informational filters.

All of these examples involve different filters that work in different ways, but each filter imvolves some form of delegation. When many people need to filter the same body of information, there are considerable efficiencies in delegating that task to someone else. The need for filtering gives rise to people who provide that service, either through market demand, through social custoin, or through governmental regulation. Filtering and delegation thus go hand in liand. And because increasing amounts of information inevitably lead to the need for filtering, they inevitably lead to the need for delegation. This gives people to whoin we delegate the construction of infornational filters an important degree of power. It is a necessary power caused by the limited space in our minds and limited time available for absorption, as well as the positive need to block harmful, useless or offensive information. The power of delegation is, if anything, enhanced in an age of exploding information. We must-and do-trust and rely on delegations to filterers to give a relatively appropriate picture of the world. For it is the picture of the world we get through informational filters that will largely determine whether we think that the people we liave delegated this power to are, in fact, doing their jobs properly. There is something iromic about this. In the Information Age, we were told, information would be power. It is turning out to be quite the opposite. In the Information Age, it seems, power does not rest with those who lrave access to information. It rests with those who filter it. 


\section{FILTERING AND MASS Media}

Let me summarize the argument so far. All commumications media produce too much information. So in that sense, all media have a problem of scarcity. But the scarcity is not a scarcity of bandwidth. It is a scarcity of audience. There is only so inuch time for individuals to assimilate information. And not only is there too much information, some of it is positively imdesirable. As a result, all media give rise to filtering by their audience, or, more importantly, by people to whom the audience delegates the task of filtering. For a filter to operate properly, any criteria of filtering must be linked to an effective ability to exclude. Many desirable ways of filtering information may not be possible or cost-effective given the nature of the media.

The problem of practical filtering exists in all media. It is inherent to any form of communication. However, the problein appears differently for different media. Media differ in terms of the kinds of blocking, selecting, and organizing filters practically available to thein. It is easy to block books and videocassette tapes, because books and videocassette tapes are individual and separate umits of consumption. They can be put in stores on shelves or locked behind counters. It is easy to keep soine out and let others in. It is also easy to put thein in different shelves according to category. They can be read or viewed in any order you choose, at any time of day.

If broadcast niedia are special, they are special in this respect: Broadcast media offer limited practical means of filtering. Parents nray want to keep their children from certain kinds of television programs. But their ability to do so is limited.

Broadcast commumication is a linear stream of information in a predetermined and unchangeable order sent out at a predetermimed and unchangeable time. This form of communication limits the ways one can filter infornation. There are basically only three: turning the receiver off completely, turning it on only at designated times, or changing the chaimel. Parental blocking is similarly limited. Parents can control children's viewing habits by turning the television off at specified times or forbidding children to watch certam channels. If children insist on watching television when their parents are not at honie or cannot supervise thein, parents have no choice other than to remove the television entirely. Because the number of filtering solutions is limited, there is a poor fit between desirable filtering mechanisins and practical exclud- 
ability. Only very coarse filters can be made to work. This coarseness is the distinctive characteristic of broadcast media.

Consider the problem from the perspective of a single broadcast station attemptimg to organize information for the benefit of its viewers. Other than simply not broadcasting a program, the only means of organizing information is to segment it by time. And that is precisely what broadcasters do. They put different types of programming on sequentially, so that viewers can choose what programs to watch by time period. Broadcasters then try to turn these limitations to their advantage, through strategic scheduling of programs as regular series at preordained times, through the use of special blocks of programming, or through repeated showings.

Not surprisingly, temporal filtering is also a major method of FCC regulation. Examples are the Prime Time Access Rule and the safe harbor provisions. ${ }^{37}$ These regulations organize programming in sequences of time and require that some programs not appear at certam times. They act like blocking or organizing filters.

It is theoretically possible, using a VCR, to convert broadcast cominunication into something like books or videocassette tapes. Imagime taping each half hour of the day on each channel on a separate videocassette tape. One conld then shuffle the order of the tapes, watching them in the desired sequence. One could also keep television programming locked up in a dresser drawer away from children. In this way one could convert the television day into the equivalent of a video library. It could then be filtered and organized in much the same way as a library or video store. But this process is expensive and time-consuming; it would require constant attention and a separate recording machine for each channel. And it does little to block children from seeing what is actually being broadcast, unless parents can make sure that children only watcl the tapes rather than the origimal.

I hope it is clear by now that the problems of filtering and regnlating broadcast media-especially where children are concerned-have nothing to do with scarcity or ubiquity. They have to do with the kinds of filters effectively available for this partic-

37. $\S 16(\mathrm{a}), 47$ U.S.C. $\$ 303$ note (Supp. V 1993) (Broadcasting of Indecent Programming; FCC Regulations) (safe harbor provisions); 47 C.F.R. $\$ 73.658$ (j), (k) (1981) (Prime Time Access Rule). 
ular medium of commumication. Broadcast media differ from other media not because of limited bandwidth but because of limited methods of filtering. Nor are broadcast media special because they involve pictures and music on a screen rather than stationary text on a page. Videocassette tapes offer the same kind of expression and are also shown on television screens, but they lend themselves to much easier forms of filtering. Because broadcast information is broadcast-sent out in single sequential streams at predetermined times-it can be blocked, selected and organized in only a limited number of ways. This is a kind of scarcity, but it is a scarcity of filtering mechanisms, not a scarcity of channels. Even if there were ten million channels, all broadcast simultaneously, these problems would still arise. The special nature of the broadcast media can now be revealed. It was never about scarcity. It was never about pervasiveness. It was always about filtering.

The V-chip and similar technologies promise to change the nature of broadcast inedia because they offer the possibility of new types of filtering mechamisins. They help the broadcast media become inore like the hbrary or the video store, although the former will never be the sanie as the latter two. The approximation would work best if broadcast and cable could offer literally hundreds of channels, so that there would always be something to watch as an alternative to blocked-out material, and so that the same or similar programs would be available at different times. Perhaps the best approximation would be a pay-per-view system, in which each home could order any available programming at any time of day. (This system could also be priced as a flat fee if that were economically feasible.) We are not yet at that point in video delivery. But we may well be in a few years' time.

The great promise of new filtering and broadcast technologies lies in these changes to the organization of the medium. When we think of the future of the broadcast media and cable, we immediately think of an increased number of chaimels, and the end of scarcity. But this is a confusion. What matters is not the mcreased number of channels by itself, but the mcreased number of channels coupled with new ways to block, select, and organize programming. If broadcast media can permit blockmg and time-shifting of programming easily, cheaply, and painlessly, they will have largely approximated the filtering status of the print media. At that point, it is hard to see why they should be denied the same First Amendment status. 
Before discussing the special problems of the V-chip, it might be helpful to ask how this analysis of filtering mechanisms applies to two other current subjects of controversy-cable television and the Internet. In Alliance for Community Media, the D.C. Circuit argued that the pervasiveness rationale for regulation of indecency on broadcast television also applied to cable television. ${ }^{38}$ Senator Exon and others have argued that protection of children equally justifies regulation of indecency on computer networks. ${ }^{39}$

The traditional reason to differentiate cable television from broadcast television is that cable channels are not scarce. But, as I have argued above, the scarcity rationale does not justify the regulation of indecency in broadcast television; the problem broadcasting faces is not scarcity of bandwidth but coarseness of filtering mechanisnis. Without sonething like the V-chip, cable television is in no better a position than broadcast television, and slould be treated accordingly, notwithstanding the Supreme Court's suggestion to the contrary in Turner Broadcasting. ${ }^{40}$ Thus, if the safe liarbor provisions are justified for broadcast television, they are justified for cable as well. And if they are unconstitutional for cable television, they are equally unconstitutional for broadcast television.

Interestimgly, in Alliance for Community Media, the D.C. Circuit took a sonrewhat different view. It upheld a regulation requiring that all indecent programming on "leased access cliannels" be segregated on a specific channel or set of channels. ${ }^{41}$ These channels must then be blocked unless the subscriber requests access in writing. It rejected the suggestion that safe harbor provisions would be a less restrictive alternative, stating that children might still watch indecent programming after hours. ${ }^{42}$

It is certainly true that segregation and blocking are alternatives feasible for cable operators but not for individual broadcasters. In this sense, cable currently provides additional filtering mechanisins that broadcast television does not. But additional mechanisms for effective filtering are a reason for less censorship,

38. 56 F.3d at 125 .

39. 142 CONG. REC. S706-07 (daily ed. Feb. 1, 1996) (statements of Sen. Helms and Sen. Coats); 141 CoNG. REC. S9770-01 (daily ed. July 12, 1995) (letter introduced by Sen. Exon).

40. See supra notes $27-28$ and accompanying text.

41. 56 F.3d at $123-25,129$.

42. Id. at 125 . 
not more. Hence the constitutionally preferable method for leased access programming should be mandatory blockmg except for the safe harbor period between 10 p.m. and 6 a.m., unless the cable subscriber requests that the blocking be removed for the entire programming day. If children are sufficiently shielded from indecent broadcast programming after 10 p.m., there is no reason to believe that they are not sufficiently shielded from indecent cable programming after 10 p.m. Adults should be able to watcli shows on cable after these liours, if they have paid for them in their cable subscription. To be sure, most cable companies may clioose to put programming likely to be imdecent-like that on the Playboy Channel-on premium channels that are routinely scrambled unless the subscriber specifically requests them. But there should be no legal bar to offering the Playboy Cliannel as basic cable, as long as the cable company abides by the safe liarbor provisions.

Once a feasible V-chip technology is in place, differential treatment of cable and broadcast television will be even less justified. Mandatory segregation and blocking of indecent programming should be completely eliminated. The blockmg technology available in the V-clip, coupled with temporary safe harbor provisions (as described more fully below), should be sufficient protection for both media; no greater restrictions on broadcast indecency sliould be constitutionally permissible.

The Internet presents an entirely different set of problems. In terms of available filtering mechanisms, the Internet much more closely resembles a bookstore or a video store than a television set in the liome. In particular, the Internet does not require temporal filtering. An Internet user can filter information on the World Wide Web by subject matter using searcli engines like Lycos or Infoseek. Indeed, filtering mecliamisms on the Web are in many cases more advanced than those widely available for much of the print media. Usenet groups-the Internet equivalent of bulletim boards-are already differentiated by subject matter. Because of information overload, the messages in Usenet groups do tend to be removed after a certam time. But these messages can be selectively downloaded and viewed at the users' leisure. In any case, many web sites and FTP sites are quasi-permanent, with an inventory that clianges no more often than that at a local Barnes $\&$ Noble. From the standpoint of available filters at least, the 
appropriate model for the Internet is the bookstore, not the television broadcast. ${ }^{43}$

The real problem facing the Internet is not the lack of appropriate and powerful filters; it is possible to divide and subdivide the information coming from the Internet in any number of ways. The real problem is the abilities of parents. If filters cannot be inade relatively costless for parents to use, they will be ineffective in practice even if available in theory. This very real coucern brings me back to the V-chip.

\section{PARENTAL CONTROL AND THE V-CHIP}

There are two standard objections to blocking filters like the V-chip. The first is that parents will be unable to use the blocking device. The second is that, even if they do, children will be able to break through and watch the programming anyway. One finds similar fears expressed about the Internet. Although parents may be able to use a program like SurfWatch to keep children off sensitive parts of the Internet, children are often more computerliterate than their parents. The parents won't be able to use the software, and the children will easily be able to break through.

To address these concerns, we must distinguish between the costs of blocking access to information and the costs of breaking through the block. It does not follow that a blocking filter that creates high barriers must itself be difficult or inconvenient to operate. A double-bolted lock is a perfect example. It is easy for hoineowners to use but difficult for burglars to break through. In like fashion, the goal should be to create filters that are relatively costless for parents to operate but very difficult for most children to bypass.

43. In cyberspace, the closest thing to the broadcast medium is the electronic chat line, but even that is really closer to the model of telephone communication. Chat lines can be segmented according to subject nratter or age requirements, and parents can then use filters to ensure that children cannot enter certain chat "rooms" which have subject matter or age requirements. The existence of plentiful and adequate filtering mechanisms means that the broadcast nodel should not apply. $C$. Sable Communications, Inc. v. FCC, 492 U.S. 115 (1989) (rejecting total ban on "dial-a-porn" services in hight of available blocknig mechanisms).

E-mail presents special problems. E-nrail nressages can be filtered by subject inatter and by thread. However, the subject matter of an e-nrail message may not disclose its indecent or harassing nature. Nevertheless, in this respect e-mail is very much like regular mail, and to this extent the constitutional forms of regulation of indecency should be the same. 
This is not a problem of constitutional law. It is a problem of technological design. Different kinds of blockimg filters differ with respect to these two variables. Childproof caps are relatively ineffective because they are difficult for parents to operate as well as children, so the parents don't use them properly. But it's quite possible to design a V-chip that parents can easily use but children will find difficult to crack. A simple example would be a four-digit number, like that on an ATM card, that enabled access to the programming menu. No doubt even these minimal costs can be further reduced with sufficient ingenuity.

Similarly, in designing Internet blockers, the goal should be to create an interface that is easy to use and that offers powerful blocking results. This task is hardly beyond the capabilities of the private computer industry. Enormous sums of money are devoted each year by these companies to produce increasingly user-friendly and increasingly powerful interfaces. The whole point of designing security features in commercial software is to nnake thein paimless for the user but difficult for the hacker.

It is important, nevertheless, to recognize that some children will be able to "hack through" the blocking devices their parents use. In any population of children, sonue will be nore clever and more coniputer-hiterate than others. Sonie will be very clever, and a few may even be able to break into Defense Department coinputers. But a filter design need not be foolproof to be acceptable as a constitutionally preferable alternative to a total ban. It need only be able to block most children or make it very difficult for them to break through.

This primciple is clear enough from the existing safe harbor provisions in broadcast television. In its $A C T$ III opinion, the D.C. Circuit acknowledged that some children would be able to expose themselves to programming not intended for them simply by staying up late, or sneaking a television into their room at night. ${ }^{44}$ Indeed, statistics quoted by the court indicate that many, although not most, children watch television after 10 p.m. ${ }^{45}$ This did not undermine the value of the ban on indecent programming between 10 p.n. and 6 a.m. Rather, the court reasoned, the safe harbor

44. See ACT III, 58 F.3d at 665 . Moreover, it is at least theoretically possible that children could tape indecent programs during the safe harbor period and view them during the hours they are awake.

45. See id. 
provisions are a reasonable balance between free expression concerns and the protection of children. If the temporal filters involved in the safe harbor rules need not be perfect in blocking all children, neither do the technological filters involved $\mathrm{m}$ the $\mathrm{V}$ chip. ${ }^{46}$

\section{The Key Issue: AvoIdING AdDitional LAYERS OF REGULATION}

I am concerned about the V-chip for different reasons. Unless the FCC regulations are carefully designed, they will simply superimpose new content-based regulations over the restrictions we now have. Witlout care and forethought, the V-chip will not liberate broadcast programming from censorial power; rather it will increasingly subjugate it.

Ideally, the V-chip should be understood as proposing a sort of constitutional bargain. In return for offering parents a method of protecting children from violent and indecent programming, the government should henceforth be forbidden from engaging in other content-based regulation of violence and indecency im the broadcast media. If the V-chip technology is inplemented properly, it will shift the focus of broadcast regulation from regulation of content to regulation of filtering of content. Most importantly, it will turn broadcast regulation towards more appropriate concerns: ensuring access to as many speakers as possible. It will move us away from an improper fixation with what slould not be on television and toward a proper concern with what unust be.

What I fear is that the V-chip will be used instead to impose an additional layer of content-based regulation on top of existing imdecency prohibitions and safe luarbor provisions. It will be used to ensure not just that children are not exposed to certam programming, but that adults are not exposed either. Proponents of censorship are mevitably tempted to protect adults in the name of protecting children. The V-chip unust not be allowed to facilitate this desire.

Courts must be especially vigilant to ensure that a "multi-layered" approach to broadcast regulation does not result. I propose

46. It is important to stress that no parental control system, like no filtering system generally, can be foolproof. Because the V-chip will be installed only im sets larger than 13 inches, children will still, in theory, be able to get around its blocking capabilities. They need only purchase a nine-inch set and a magnifying glass. 
a general principle for assessing the constitutional use of technological filters like the V-chip. Because lack of effective filtering mechanisms is the real justification for content-based regulation, creation of new and more effective filtering devices should always create heavy presumptions against any reniaining content-based restrictions. The more easily and broadly a V-chip or other technological filters can be implemented, the more suspect must be any restrictions on violent and imdecent broadcast programming.

The safe harbor provisions offer a good example of how to apply this principle im practice. Even after the V-chip has been perfected, there still may be a limited and tenuporary need for the safe harbor provisions. By its terms the Telecommunications Act of 1996 apphies only to television sets over thirteen inches, and its requirements do not take effect until at least two years after the date of the Act. ${ }^{47}$ Not every television is likely to be replaced as soon as the V-chip is introduced; even though the V-chip can be encoded in a cable box, not all families will immediately rush out and get one. Televisions (and replacement cable boxes) cost money. Most likely there will be a significant period in which many families lack the V-chip. For this reason, it may be necessary to retain the safe harbor provisions for a "sunset" period of, say, seven years. ${ }^{48}$ After that point, anyone who uses a non-V-chipcompatible television would be on notice that it would not be able to block out prograins. If they wanted that capability, they would have to purchase a V-chip-equipped television or a V-chipequipped cable box. If they refused to upgrade their equipnent after seven years, they would have only themselves to blanie if they were shocked and surprised by what they saw while flipping channels.

The regulatory schenie should not, however, use the lack of V-chip capability as an excuse to pile on additional regulations that put broadcast programming in a worse position than it was in before the Act. The regulatory scheme should not require that the

47. $\S 551(\mathrm{c}), 110$ Stat. at $141 ; \S 551(\mathrm{e})(2), 110$ Stat. at 142.

48. This figure depends on how one sees the likely future of technological development. If the V-chip is placed in standard cable boxes or in inexpensive add-on devices, it is reasonable to assume that inost households that want thein will purchase thein more quickly, and the sunset period could be reduced accordingly. If, on the other hand, the V-chip is mainly implemented through new television sets, then something like ten years may be necessary for most old sets to wear out and be replaced. 
safe harbor rules remain in force indefinitely merely because soine televisions do not yet have V-chip equipment.

\section{THE RATINGS SYSTEM}

The development of a ratings system poses a second constitutional problem. The Telecommunications Act of 1996 is cleverly drafted to create an almost irresistible set of pressures on private industry to create and implement a voluntary ratings systein. It does so because, as the drafters well realized, a government-created ratings system imposed against the will of broadcasters would pose serious constitutional issues. Thus, the Act prescribes that "distributors of video programming" have a year to coine up with a workable ratings system acceptable to the FCC, "in consultation with appropriate public interest groups and interested individuals from the private sector." ${ }^{\text {49 }}$ If private industry does not coine up with rules satisfactory to the FCC, the job will fall to an advisory committee appointed by the FCC. This advisory committee would be coinprised of "parents, television broadcasters, television programming producers, cable operators, appropriate public interest groups, and other interested individuals from the private sector." ${ }^{\text {50 }}$ Not surprisingly, this committee sounds like the same groups the FCC would probably consult to determine the acceptability of any industry ratings systein.

The Act's "fail-safe" provision deliberately stops short of requiring that broadcasters accept the ratings system devised by the advisory committee. It requires only that, if video programming already is rated by the broadcaster, the rating must also be encoded so that it can be read by a V-chip system. ${ }^{51}$ Left unclear is whether the Commission would be empowered to require that broadcasters accept the advisory committee's rating system. Also left unclear is whether the FCC would have the power to insist that all programming be rated before it can be broadcast.

49. $\S 551(\mathrm{e}), 110$ Stat. at 142 . At a meeting held on February 29, 1996, leading representatives of the media industry agreed in principle to provide a private ratings system by January 1997. Alison Mitchell, TV Executives Promise Clinton a Violence Ratings System by '97, N.Y. TIMES, Feb. 29, 1996, at A1.

50. $\S 551(\mathrm{~b})(2), 110$ Stat. at 140 . The advisory committee is to be "fairly balanced in terms of political affiliation, the points of view represented, and the functions to be performed by the committee." Id.

51. $\S 551(b), 110$ Stat. at 140. 
The fail-safe provision is left deliberately toothless to avoid constitutional problems of prior restraint and compelled speech. Instead, the true goal of the legislation is to present broadcasters with a set of unpalatable alternatives. If they do nothing, they risk the appointment of an advisory committee telling them low to rate their programs. Even if the FCC cannot constitutionally require that they accept the ratings system as a condition of broadcasting, there will be enormous public pressure on broadcasters to accept a system that has already been worked out with attendant public fanfare. Faced with this possibility, broadcasters and distributors will instead choose to create their own ratings system. ${ }^{52}$ The recent meeting between President Clinton and media representatives suggests that the pressure has already been felt and mdicates that the media mdustry will take whatever steps are necessary to head off a government-appointed advisory committee..$^{53}$

This is precisely what the FCC hopes will happen. If the industry creates its own ratings system, the FCC actually has inuch greater power and influence than it would have under the fail-safe provisions. The FCC can decide whether to approve the ratings system or not, using basically the same players that would have formed an advisory committee. If the industry does not conform sufficiently to the FCC's wishes, the FCC can declare the industry not to be im compliance and once again loold up the threat of an advisory commission.

The result of this calculated gamesinanship will be a set of guidelines largely acceptable to the FCC and implemented without government expense or the creation of a new governmental bureaucracy. Moreover, because the guidelines are "voluntary," the FCC does not liave to require that broadcasters accept them, or

52. For similar reasons, if one broadcaster then decides to rate its programming, others will feel enormous pressure to follow suit. Thus, when Rupert Murdoch broke ranks and announced that his FOX network would rate shows regardless of what the other networks did, he made it virtually inevitable that NBC, CBS, and $A B C$ would agree to a ratings system. See March Gunther, Fox Leads Pack in Vow to Adopt Ratings System, TIMEs-PICAYUNE (New Orleans), Feb. 16, 1996, at C1.

53. Alexandra Marks, TV Industry Problem: Rating 400,000 Shows, CHRISTIAN SClENCE MONITOR, Mar. 1, 1996, at 3 (noting that media companies originally resisted Vchip ratings but ultimately decided to "declare victory" and capitulate). CNN founder Ted Turner-who supports the V-chip-put it best when he wryly noted that "we're voluntarily having to comply." Kathy Lewis, TV Ratings Promised by January, DALLAS MORNING NEWS, Mar. 1, 1996, at $1 \mathrm{~A}$. 
issue regulations that all shows be pre-screened. It need merely insist on these conditions as the price of its approval of the "voluntary" ratimgs system. In this way the FCC can achieve through threats much of what it could not have achieved through direct regulation.

Although the clever drafting of the legislation is designed to avoid constitutional problems, the very idea of an advisory committee, whether as an actual ratings body or as a threat the FCC hopes never to employ, is constitutionally troubling. From one perspective, there is no problem with the government designing a content-based information organization system and leaving it up to private parties to decide whether to accept or reject it. For example, there is nothing unconstitutional about the development of the Library of Congress cataloguing system or its near universal acceptance in public and private libraries as a means of organizimg information. The problem comes when the government insists that information must be organized according to content in a certam way or it cannot be published at all. And when the government uses threats, whether overt or concealed, to achieve this result, constitutional values are surely implicated.

The first problem that any ratimgs system will face is what to do about unrated programming. Must all television programming be given a V-chip ratimg, or only some of it? ${ }^{54}$ Must all programming be submitted for ratimgs, or can a broadcaster refuse to accept or provide a rating? Most importantly, if less than all television programming is rated, can the unrated shows still be broadcast?

Although the 1996 Act does not specifically require that all programming be rated before it can be broadcast, this is clearly the eventual goal of the V-chip system..$^{55}$ Once a ratings system is

54. Current estimates suggest that there are over 600,000 hours of programming yearly on a 70-channel cable system, as opposed to around 1,200 hours of movie programming rated annually by the Motion Picture Association of America. Ed Bark, TV Ratings Sure To Be a Daunting Task, DALlAS MORNING NEws, Mar. 1, 1996, at 24A.

55. The Act is deliberately ambiguous on this point. To avoid the fail-safe provisions, "distributors of video programming" must "establish] voluntary rules for rating video programming that contains sexual, violent, or other indecent material about which parents should be informed before it is displayed to children," and "agree[] voluntarily to broadcast signals that contain ratings of such programming." $\$ 551(\mathrm{e})(1), 110$ Stat. at 142 . The Act does not say that all such programming must be rated-only that rated programming be broadcast as rated. However, it is hard to believe that the FCC would be satisfied with a result in which an industry ratings system was developed but not implemented on 
in place, the FCC can then issue regulations to discourage or segregate unrated programming. Chairman Hundt has specifically contemplated such a strategy. He argues that any programs that remain unrated can constitutionally be relegated to the safe harbor period. ${ }^{56}$ Yet this solution is too facile. It threatens to put enornous numbers of programs in a worse position than they were in before the implementation of the V-chip. It violates the key constitutional principle I have enunciated: that the development of new technological filters should decrease government restrictions on adult viewing, not increase them.

A requirement that all programs be submitted to a private industry council before they can be screened has many of the features of a prior restraint. The problems would be even greater if the ratings (or the guidelines for thein) were entrusted to a government-appointed Television Commission. But it should also be constitutionally troublesoine for government to insist that speakers gain the imprimatur of a delegated private organization before they can be allowed access to the airwaves.

The goal of the 1996 Act is that broadcasters will voluntarily rate their own programming, making the prior restraint problems vanish. But not all broadcasters will be able or willing to do this for all of their programming. Many people who speak over cable and over the airwaves are not networks or network affiliates. They will necessarily have to rely on third parties to pre-screen their inaterial. Thus, the problein of pre-screening by some organizatiou other than the speaker cannot be avoided. ${ }^{57}$ This is especially so

a virtually universal basis, at least for pre-recorded programming other than news and sporting events. Even if individual members of the Commission could accept such a fig leaf, pohitical pressures against it would be almost unbearable.

56. Hundt, supra note 15, at 1129.

57. A press conference following the February 29, 1996 agreement between President Clinton and major media executives revealed some of the potential problems. Jack Valenti, president of the Motion Picture Association of American, suggested that, because of the mammoth task of rating thousands of hours of programming, program distributors (as opposed to program producers) would have to rate their own shows. When asked the obvious question about what would happen if producers and distributors disagreed about a rating, Valenti suggested, "We'll cross that river when we get there." Media Industry Agrees to Rate TV Programs by 1997 for Use with V-Chip, DAILY REP. FOR EXECUTIVES, Mar. 1, 1996, \& A, at 41 .

At the same press conference, Decker Anstrom, president of the National Cable Television Association, argued that cable networks, but not cable operators, would do the rating. However, National Association of Broadcasters President Ed Frits opined that networks would rate their own shows while syndicators and local stations would rate 
if the government is seriously interested in ensuring conformity of ratings among different program distributors. For example, without a credible third-party enforcement mechanism, sone distributors may be tempted to "underrate" programs because they fear that a more stringent rating would reduce advertising revenues. ${ }^{58}$

It inay be objected that the requirement of pre-screening and pre-rating is not really a prior restraint, because all unrated programming can still be broadcast during the safe harbor period. But this argument is deficient on two grounds. First, as argued above, the safe harbor regulations must gradually be phased out after the new system is adopted. Second, and nore important, the unconstitutionality of a prior restraint is not avoided even if there is another means of expressing one's self. Imagine a city ordinance that required all leaflets in the downtown area to be pre-screened for appropriate content by the City Manager. ${ }^{59}$ The constitutionality of this ordinance would not be saved by the fact that one could distribute the leaflets in the subnrbs or simply write letters to the editor.

My view is that the government cannot constitutionally require that all unrated programming inust be shown during the safe harbor period, although it can require that, during a seven year "sunset" interval, all unrated indecent programming be shown during the safe harbor period. It can do so because-assuming that the current safe harbor period regime is constitutional-unrated indecent programming would be no less protected before the Act than after it. ${ }^{60}$

Nevertheless, the government nust allow all other programming to be shown outside of the safe harbor period whether it is

theirs. If a local station did not agree with a rating supplied by a network, it would be free to change the rating. Id. These remarks suggest that the rules abont who would do the rating or have the final say might differ for cable and regular broadcast programming.

58. There is also the related danger that the same program might receive different ratings from different distributors. The media representatives' agreement with President Clinton sought to allay these concerns by promising to establish an oversight group that would periodically review ratings of specific programs and comment on whether they met the industry's ratings guidelines. Lewis, supra note 53.

59. Cf. Lovell v. City of Griffin, 303 U.S. 444 (1938) (striking down prohibition of distribution of literature in city streets without permit from City Manager).

60. Assuming that safe harbor rules for regulation of particularly violent programming would be constitutional under the current regime, a similar argument would apply to this programming as well. 
rated or not, and whether or not it has been submitted to a third party. When broadcasters cannot or will not rate programs by themselves, the government must place the burden on third-party ratings systems to provide ratings in time for broadcast. It cannot put the burden on broadcasters to obtain or accept a rating before broadcasting.

To see why the burden unust rest on the ratings board and not on broadcasters, consider the probleins involved with blocking access to three different groups of unrated programs: The first are pre-Act programs, the second are news programs, and the third are broadcasts of hive events, including sporting events.

There is currently an enormous backlog of programs produced before the development and implementation of the V-chip. They include biterally everything heretofore recorded on movie film or videotape. If the concern is sexual content and violence, many parents might well want to restrict access to inuch of this pre-Act inaterial. But if this nnaterial would not have fallen afoul of the indecency standard of Section 1464, it is doubtful whether the government could constitutionally require it to be shown only during the safe harbor period. The contrary result would be ludicrous: Imagine the federal government holding that a rerun of " $\mathrm{M} * \mathrm{~A}^{*} \mathrm{~S} \mathrm{H}^{\mathrm{H}}$ " or "The Mary Tyler Moore Show" origmally broadcast during prime time in 1975 must now be shown after 10 p.m. because it has not yet been rated.

The constitutional problems are even more obvious when we coine to programs like news reports that often cannot be prepared well in advance. Should we say that the "NBC Nightly News" cannot be broadcast except in the safe harbor period because Tom Brokaw did not pre-screen it with an industry council? And should the same reasoning apply to CNN broadcasts from the former Yugoslavia or the latest results froin the New Hampshire primary?

Live performances present similar difficulties. Industry officials can surely pre-screen scripts if they are available. But the government must not be able to shunt all hive performance into the safe harbor period simply because a bureaucracy cannot pre-screen it. It is important to stress that when we talk about hive programming, we are not speaking primarily about raunchy talk shows at two o'clock in the afteruoon. We are talking about the World Series and the Super Bowl, as well as late-breaking news and public affairs programming. I doubt Chairman Hundt would insist that 
President Clinton give his State of the Union Address during the safe harbor period because the speech had not been prescreened. ${ }^{61}$

The constitutional problems posed by unrated programming can easily be solved. V-chip technology should be designed to allow viewers to block out all unrated material. This puts the onus where it belongs, on the parent to avoid watching unrated material, rather than on the networks to rate it. In addition, the FCC should permit broadcasters to insert a special category code for news and public affairs programming, a code that could be routinely assigned to local and national news programs without prescreening for sexual and violent content. (Another code could be offered for sports programming). Parents then would have the option of watching or not watching such programming on the assumption that the vast inajority of news and public affairs programming will not be harmful to children even though it will not have been pre-screened.

The preliminary agreement between President Clinton and media executives contemplates that sports and news programming will be unrated. ${ }^{62}$ However, because inuch adult-oriented and experimental programming will also be unrated, the industry's solution is likely to cause problems in the future. By giving all news (and sports) programming a special ratings code, we would prevent these programs from being lumped together with all other "unrated" programming. This would allow parents to avoid all unrated programming and still watch news and sports without constantly having to change the settings on their V-chip. ${ }^{63}$ If news and sports programming remam unrated, the danger is not that people will refuse to watch news and sports programming. The danger is that there will be enormous pohtical and financial pressures to ensnre that all unrated programming is acceptable for all children, so that unrated programming becomes equivalent to a $\mathrm{G}$ movie rating. The latter result is the exact opposite of what a V-chip system should accomplish.

61. Of course, given President Clinton's natural propensities, the speech might go on into the safe harbor period anyway.

62. Joln M. Broder \& Jane Hall, President Hears TV Executives Commit to Ratings System, L.A. TIMES, Mar. 1, 1996, at A1.

63. This is in keeping with the general goal, discussed earlier, of creating a filtering systein that requires as little effort by (and as little technological sophistication of) parents as possible. See supra part V. 
I have argued that the constitutional problems of prior restraint can be avoided only if programs can be shown without prescreening or pre-rating; the burden must be on an external rating organization to provide ratings in time for broadcast. One might object that my solution allows broadcasters to do an end run around the V-chip; they can simply refuse to provide or obtain ratings, and put on violent and sexually charged programming without effectively being blocked out. But this result is unlikely to occur as long as parents are empowered to block out all unrated prograins. Broadcasters, after all, are not insensitive to advertisers, and advertisers will be unlikely to spend their dollars on unrated programming if they beheve that a substantial number of parents will block such programming. Thus, even without the use of a prior restraint, broadcasters will have considerable financial incentives to submit all programming to a private industry ratings board (or rate it themselves) when they can. In the case of hive broadcasts, they will take whatever steps are necessary to guarantee a rating beforehand. Thus, for the vast majority of programming that most families want to watch, it will be possible to obtam a rating before broadcast. This is especially so if broadcasters are permitted to give news and sports programming a special ratimg without pre-screening. ${ }^{64}$

This solution is not without costs. Local cable access programming and other programs that do not or caumot submit to ratings can still be shown under iny proposed solution. However, they will not be picked up in the homes of parents who have blocked out all unrated prograins. Moreover, my solution will still tend to segregate programming that does not submit to pre-screening along with programming that remains unrated for strategic rea-

64. The use of a special code for live news and sports raises its own problems. Among the most obvious is whether faux-journalism shows like "Geraldo" and "Hard Copy" should be classified as "public affairs programming" along with the "NBC Nightly News" and the State of the Union Address, or should be treated under the general ratings system. There are reasons to think that the latter solution is preferable, especially if a program devotes a substantial amount of its air time to sexually charged material. But this leads to dicey questions about what is "really" news and public affairs and what is not. See Jane Hall, TV Content-Rating Planners Weigh Category Refinements, DALLAS MORNING NEwS, Apr. 7, 1996, at 2C.

The concern about "Geraldo" is, of course, symptoniatic of a larger problem. If media executives really played fair in assigning V-chip ratings, it might well turn out that the vast majority of daytime television-lurid talk shows and steamy soap operas-is unsuitable for children due to its pervasively sexual content. Perhaps it's a good thing nost kids are in school during those hours. 
sons-for example, sexually explicit and violent programming. This will result in a smaller audience for such programming, and less advertising revenues. But it nevertheless ensures that people who want to watch this programming can have access to it, and at any time of day. In this sense it is more consistent witl First Amendment values than the alternative.

\section{THE V-ChIP AND THE DELEGATION OF INFORMATIONAL FILTERING}

So far, I have spoken only about the constitutional issues raised by the V-chip. Yet the deeper problems that the V-chip raises lie elsewhere, and it is likely that these problems are not constitutionally cognizable ones. They concern the power over individual thought and national culture that arises with increasingly powerful forms of delegation of informational access. This problem is by no means new. Delegation of informational access has always existed in one form or another. But my concern is that, in the Information Age, the sliape of culture will increasingly be determined by tliose persons and organizations who organize, filter, and present information for otliers and to others. I fear that neither the proponents nor opponents of the V-chip fully grasp this fact. Although these features already exist in the world we now inhabit, they will surely be magnified in the world we now enter.

The regulatory apparatus surrounding the V-chip will work an enormous new delegation of informational filtering to a centralized bureaucracy, whetler one operated by the federal government or one operated by private industry. ${ }^{65}$ This new bureaucracy will be entrusted witl the task of devising and implementing filters for virtually all of the television programs available in the United States. It will have to determine both the salient characteristics of all programming and evaluate which programs fit within the boundaries defined by these characteristics. These characteristics and these evaluations will in turn be employed by viewers and, more importantly, by advertisers, cable providers, video rental stores, public libraries, television production companies, writers, coniposers, and directors. As these evaluations becoine commonly

65. The Telecommunications Act of 1996, for example, provides that the advisory committee shall be assigned "such staff and resources as may be necessary to permit it to perform its functions efficiently and promptly." $\$ 551(b)(2)(B), 110$ Stat. at 141 . 
employed, further choices and social arrangements will then be organized around them. In this way, the divisions of the cultural and informational world created by the custodians of the V-chip, however innocent, will be amplified throughout our culture, shaping and skewing the social world $\mathrm{m}$ unforeseen ways. It is possible that we shall have nothing to fear from these effects. But it is equally likely that there is much to fear. It is probable that soine version of these effects is inevitable. But it is certain that no particular version is inevitable.

Filtermg inechanisnis are not neutral ineans of organization, blocking and selection. They have inportant effects on what kinds of inaterials are subsequently produced and how social arrangeinents are subsequently organized. People who produce and receive information respond to and organize their lives around the existing forms of filtering. I do not yet know the many ways that the filtering inechamisnis devised for the V-chip will affect our culture. Indeed, I am quite sure that we will not be able to recognize them for inany years after they have already taken hold. All I can do here is offer the most minor exanıples of inechanisins that may have inajor consequences.

I want to focus on three basic kinds of effects. The first has to do with what characteristics are salient in forming categories-for exanple, bad language or nudity. The second has to do with coarseness-how fine-grained the filtering categories are. The third concerns equivalency-what kinds of things are seen as parts of equivalent categories. These factors overlap, but they are also distinct. Two ratings systenis can be equally coarse and yet view different characteristics as salient. Moreover, two ratings systenus can be equally coarse and view different sorts of things as equivalent in each category. Consider two ratings systeins that each have ouly two categories. The first systein holds that any profane language or any inention of contraception places a prograin in the adult category, while the second includes only profanity. The two systenis are equally coarse, but they have different senses of equivalency. In the first system, profanity and discussions of contraception are treated alike as inappropriate for children; in the second systein they are treated differently.

The first problein of any ratings systen is what characteristics count in inaking programming unsuitable for children. The most likely ratings system will focus on the categories of sexual content, 
nudity, violence, and profane language. ${ }^{66}$ These factors basically track the considerations currently employed by the Motion Picture Association of America (MPAA) ratings system. ${ }^{67}$ It is much less likely that racist, sexist, or homophobic language and depictions will be included as salient categories. Yet if parents are concerned with what their children pick up from television, they might be particularly concerned whether their children are picking up habits of intolerance. The harm to our children from these influences, one might think, would be equally as great as the harm from exposure to sex, violence, and bad language. And both sets of criteria involve content-based distinctions.

Nevertheless, it is very unlikely that either an industry ratings board or an FCC-appointed television advisory committee will code for racist, sexist, or homophobic expression. The Telecommumications Act of 1996 expressly states that ratings systems are to avoid political and ideological categorizations. ${ }^{68}$ These bodies will

66. For example, according to the Telecommunications Act of 1996, the Television Commission is charged with "rating of video programming that contains sexual, violent, or other indecent material about which parents should be informed before it is displayed to children." $\S 551(\mathrm{~b})(1), 110$ Stat. at 140.

67. The February 29, 1996 agreernent between President Clinton and representatives of the media industry contemplates that the eventual industry system will resemble the MPAA system, even if it will not necessarily be identical to it. Broder \& Hall, supra note 62 , at $\mathrm{A1}$; Marks, supra note 53 , at 3 .

One major problem with the current MPAA system is that the ratings are awarded by a committee of laypersons who have no particular expertise in what kinds of violence are actually the inost harmful for children to watch. So it is likely that some movies rated $R$ for their violence may actually be less harmful than soine rated PG-13. Of course, there is no guarantee that an industry-produced ratings system will match the results of psychological studies any better.

68. The Act insists that "nothing in [the requirement of ratings provisions] shall be construed to authorize any rating of video programming on the basis of its pohtical or religious content." $\S 551$ (b)(2), 110 Stat. at 140 . Furthermore, the advisory committee that informs the television commission is to be "composed of parents, television broadcasters, television programming producers, cable operators, appropriate public interest groups, and other interested individuals from the private sector," and is to be "fairly balanced in terms of political affiliation, the points of view represented, and the functions to be performed by the committee." Id.

One assumes that the same caveats will apply to any industry-created ratings system, since under $\S 551(\mathrm{e})(1)(\mathrm{A})$ of the Act the FCC will not issue guidelines for ratings if private industry lias established rules "acceptable to the commission." § 551(e)(1)(A), 110 Stat. at 142.

By contrast, under the ratings systein now benig tested in Canada, "language offensive to minorities or ethnic groups" can be blocked out by a V-chip. It gains a rating of 3 ont of a possible 5 on the language scale, with 5 being the most offensive. Verne Gay, Ratings Soon: TV Industry to Code Shows by Next Year, NEWSDAY, Mar. 1, 1996, at A3. 
probably argue that coding or blocking programming as racist, sexist, or homophobic would give the unmistakable appearance of political favoritism.

Yet this objection reveals the problems that already exist with the inost likely system of ratings-one organized around depictions of sexual conduct, violence, and profanity. The choice to protect our children from these things rather than others cannot be said to be truly apolitical, even if it can be assured to be mainstream. While overt expressions of homophobia are likely to remain uncoded, overt homosexual expressions of affection will probably be among the first to be coded as inappropriate for children. The social equality of homosexuals is currently a political lot potato, and one is quite sure in which direction this particular potato will get dropped. ${ }^{69}$

The very assumption that exposure to racist messages is less harmful to our children and our commumity than exposure to violence already carries considerable political freight. Although coding for violence but not for racism seems to exclude political and ideological controversy, it does not avoid politics or ideology. Ratler it installs them in the very process of coding. The actual practice of political and religious "neutrality" will be aclieved by the selective avoidance of topics; it will produce the appearance but hardly the reality of apolitical judgment. ${ }^{70}$

In effect, the Canadian system equates the "F-word" with the "N-word;" it thus raises many of the problems of equivalent degrees of offensiveness discussed infra. Moreover, under this system, even though racial epithets are coded, they are judged less offensive than many other possible expressions. Id.

69. Coding for violence and for homophobia both involve content-based distinctions. However, it may be objected that coding for violence, unlike homophobia, is viewpoint neutral. But this example shows how tenuous this distinction can be in practice. Simple, ordinary demonstrations of affection between gays-the kind that would pass unnoticed between heterosexuals-are important means of showing the normalcy of gay hives and the commonality of their basic concerns with those of straight audiences. Yet these displays are likely to be judged unsuitable for children while negative portrayals of gays will pass unfiltered by the system.

70. My point in raising these difficulties is not to call for the coding of racist expressions. It is rather to note the pohitics imphicit in a coding system that focuses on violence and indecency to the exclusion of other factors. Coding for racist messages, even if constitutional, would prove very difficult in practice. Often racial stereotypes are used in ironic ways, in which it is difficult to tell their actual meaning, much less their long term effects. Black-oriented comedy shows like "In Living Color" and "Martin" routinely employ exaggerated racial stereotypes of mimorities. It is difficult to know where one would begin in classifying this material. 
Many people would probably be content with a ratings system that, even if not guaranteed to be nonideological, would at least be doggedly centrist. That is probably the best reason to have an industry-sponsored ratings system, which will cater to the tastes (or, more appropriately, the fears) of advertisers. But if ratings guidelines are entrusted to a federally-appointed television advisory committee, there is no guarantee of even this. Rather, the protection of family values through a ratings systen is likely to take on decidedly different pohtical spims under successive administrations. Nothing prevents a future committee from changing its mind about ratings guidelines if they should prove unsatisfactory or outmoded. And if the FCC has control over who sits on such an advisory committee, the guidelines produced by that committee will probably change over time depending on the regnant political forces (including subsequent Presidential appointments to the Commission).

Chairman Hundt, an appointee of President Clinton, would be in charge of assembling the first such advisory commission. Neither Clinton nor his appointees are immune from political pressures, as the very decision to run the 1996 presidential campaign on "values" issues like the V-chip clearly shows. Even so, one wonders whether the ratings system produced under the watchful eye of an FCC commissioner appointed by President Pat Buchanan or even President Robert Dole would not differ from one produced under Chairman Hundt's supervision. The nore the FCC becomes involved in the ratings system, the nore heavily that system will becoine pohiticized. It is pohtics, after all, that has led to the new systenı, and politics will not soon depart once the system is in place.

Once again, this is not to say that industry-developed ratings will be less affected by pohtics. ${ }^{71}$ Any industry-developed ratings systen inust still be approved by the FCC. Moreover, it is likely that future politicians will attempt to make political hay by bash-

What advocates of rating systems may not realize, however, is that similar problems apply to depictions of violence. Violence is often used to show a character in a bad light, or to punish the wicked and the violent. Much violence is portrayed in a cartoonlike fashion. The many ways in which violence can be depicted, and the many social meanings it can convey, underscore that, hike racist expression, there will be no easy way to code it.

71. Although it is quite probable that the wishes of advertisers will have a more direct and substantial effect. But it is hard to know whether this is cause for rejoicing. 
mg any industry ratings system and threatening a government takeover. Just as Senator Dole today boosts his campaign for the presidency by denouncing the wickedness of Hollywood, pseudopopulists of the future will discover an irresistible temptation to denounce whatever ratings system emerges as toothless and sinful, endangering the lives of our children and the future of America. Thus, even if the imdustry adopts its own system, the result may still be pohticized. The use of industry-developed ratings is only the lesser of two considerable evils.

Coarseness of the ratings system is a second major concern. The current motion picture ratings system is perhaps the best example of how coarseness operates im practice. The MPAA currently offers a rating system featuring six categories-Unrated, G, PG, PG-13, R, and NC-17..$^{2}$ Ratings are determined by a panel of full-time employees using a combination of factors, including theme, violence, sexual content, and language. ${ }^{73}$ Because these factors are taken together rather than differentiated, motion picture producers face a relatively coarse filtering mechanism. In fact, the PG-13 category was added later on because the previous systein included too inuch in the PG category. ${ }^{74}$

Soine effects of the system occur at the far end of the spectrum. Producers know that an NC-17 rating will significantly cut into movie sales. Many movie theaters will not show NC-17 novies, ${ }^{75}$ many newspapers and television stations will not advertise them, ${ }^{76}$ and they are not carried by nnajor video chains like Blockbuster. ${ }^{77}$ Hence producers take great pains to gain an $\mathrm{R}$ rating froin the MPAA board, often offering to cut out offending materials. ${ }^{78}$ Although the desire to obtam an $R$ rating may pro-

72. The $\mathbf{X}$ rating originally devised by the motion picture industry has been abandoned, and is now used primarily by adult video producers as a way of einphasizing the salacious nature of their product. See Leonard Klady et al., Sticks Can't Nix Naughty Pix: 'Showgirls' Wide Release Pushes NC-17 Envelope, VARIETY, July 24-30, 1995, at 1.

73. Jack Valenti, The Voluntary Movie Rating System, in THE MOVIE BUSINESS BooK 396, 401-02 (Jason E. Squire ed., 1992); Richard P. Salgado, Regulating a Video Revolution, 7 YALE L. \& POL'Y REV. 516, 519-20 (1989).

74. Richard Zoglin, Gremlins in the Rating System: Two Hit Films Raise New Concerns About Protecting Children, TIME, June 25, 1984, at 78.

75. Rachel Eisendrath, Film Industry Rates NC-17, MONTGOMERY ADVERTISER, Oct. 29, 1995, at $1 \mathrm{H}$ (reporting decision by Carmike Cinemas, a chain of 2,104 screens scattered through the South, not to show "Showgirls" because of its NC-17 rating).

76. See Richard Corliss, What Ever Became of NC-17?, TIME, Jan. 27, 1992, at 64.

77. See Joln Greenwald, Wayne's World, the Sequel, TIME, Oct. 11, 1993, at 64, 67.

78. Although the director does not directly negotiate with the film board, strategic 
duce self-censorship, movies with an $\mathrm{NC}-17$ rating can still be shown to consenting adults.

A more curious and perverse effect happens on the other side of the ratings spectrum. Although a $\mathrm{G}$ rating signifies that a movie is suitable for all audiences, it also tends to drive away teenagers and young adults, who are among the most avid consumers of movies. As a result, the ratings system produces a perverse incentive to "dirty up" pictures to make them attractive to a wider audience. ${ }^{79}$ Apparently many Americans dernand genume family entertainment; they just don't want to have to see it theinselves.

Any system of ratings will produce self-censorship because movie makers fear losing a desired audience. A novie producer has to balance the potential gams that might come from a change in content with the loss resulting from a corresponding change in movie rating. But the more important coarseness effects occur in the middle of the ratings spectrum. A ratings system that does not differentiate between sex, violence, and profanity will actually encourage the use of all three. For example, suppose that as a result of using several four-letter words a movie gams an $\mathbf{R}$ rating. At that point the inovie director has every reason to put in additional sexual content and violence if she beheves this will increase audience attention, as long as she doesn't cross the line into NC-17. She is guaranteed not to lose audience share because of a change in rating but she can hope to gain audience share by strategically increasing sexual or violent content. As a result, movies in the middle range of ratings may tend to get progressively more violent and more sexually explicit at the same time.

If, as seems likely, the V-chip system uses ratings as coarse as the MPAA, the broadcast world will display similar effects. The MPAA ratings resemble the anthropologist's two basic categories of the sacred and the profane. There is a category of that which is

behavior is apparently not uncommon. Martin Scorcese was reported to have deliberately added ultraviolent material to his film "Casino" so that later cuts would seen tame by comparison, thus enabling him to keep in material he thought essential. Steve Daly, In the Ratings Game, Ultraviolence is the Ace in the Hole, ENT. WKLY., Aug. 18, 1995, at 8. Another possible alternative is to refuse the MPAA rating and release the film as unrated. See Edward Guthmann, Director Finds Gender Does Matter, S.F. CHRON., Nov. 25,1995 , at $\mathrm{C} 1$ (describing the decision to release "When Night is Falling," a drama which included two lesbian love scenes, as unrated). But this does not avoid stigma, and indeed, may even invite it.

79. Film Censors; Child-Minders, THE ECONOMIST, Aug. 13, 1994, at 78. 
suitable for children (taking the role of the sacred) and a category in which everything else-violence, bad language, nudity, hoinosexuality-gets thrown in indiscriminately (the profane). ${ }^{80}$ What is profane is then subdivided not by kind of expression but by degree of profaneness, resulting in a world consisting of what is sacred, a bit profane, a lot profane, and seriously profane. ${ }^{81}$

On the other hand, if substantive categories are increasingly differentiated, the system produces a different set of incentives. It inay pay for the director to produce a film with increased violence but not sexual content, and vice versa, because a change at the margins is better reflected in the ratings system. Of course, the more categories are added, the more difficult it becomes for parents to operate the systein. As noted earher, one of the nost important constraints on the V-chip systein will be ensuring ease of use to technologically-challenged adults. ${ }^{82}$ So the result is likely to be a coinpromise between coarseness and adequacy of ratings.

A third and final set of problems with any ratings systein concerns equivalency. Even after the basic categories are determined, any ratings system will have to decide what gets coded within each category. More important for present purposes, it will have to decide what gets coded as possessing equal levels of inappropriateness. Like decisions about the categories themselves, these decisions cannot avoid pohitical controversy; they are hikely to have wide-ranging effects.

Take, for example, discussions of homosexuahity or of safe sex as a ineans of preventing AIDS. How should these be coded in a ratings system? And what should they be coded as equivalent to? Some parents would see a big difference between such discussions and a sexually titillating love scene, while other parents would fimd both categories equally unsuitable for people under the age of

80. Richard Corliss, It's Great! Don't Show It! A Misguided Rating System Slaps an $X$ on a Discreetly Erotic Film, TIME, Sept. 17, 1990, at 70 (discussing NC-17 ratings given to Director Philip Kaufman's film, "Henry and June," and controversies over other films involving lesbian scenes).

81. Note that the categories do not necessarily have to be organized around content. They can also be organized around age, much like children's toys. Thus, one can have programming suitable for children over age 4 , children over age 8 , children over 13 , children over the age of 17 , and so on. The MPAA ratings system does this to some degree, with its $\mathrm{G}, \mathrm{PG}-13$, and $\mathrm{NC}-17$ ratings. The substance of age-based ratings, however, ultimately derives from decisions about underlying content.

82. See supra part V. 
eighteen. Now imagine a made-for-television movie that depicts a fictional cover-up by the church hierarchy of child abuse allegations inade against Cathohic priests, and a movie in which Freddy Krueger murders a hapless teenage couple having sex in the woods at midnight. It is not difficult to imagine different groups of parents disagreeing heatedly about the relative inappropriateness for children of these two examples.

Questions of equivalency severely test any facade of political neutrality. Does the ratings system regard two men kissing as equivalent to a woman being raped or another being slashed with a knife? Does the system regard a discussion of contraception as nore or less inappropriate than a discussion of drug use? Whether or not we regard these events as really being different in kind is irrelevant. What is important is whether the ratings systen makes thein equivalent, by coding them as equally appropriate or inappropriate for children. Once materials are coded as equivalent, they becoine equivalent for all purposes for which the ratings system is used. And, nuake no mistake, the ratings systen will be used for purposes other than its designers intended.

Advertisers deciding where to invest their dollars, video rental stores purchasing and organizing inventory, parental groups demanding tighter controls on undesirable programming, and consumers searching for suitable entertainment will not easily be able to differentiate within categories created by a ratmgs system. They will not have to. Rather, they will use the ratings system to avoid having to engage in such differentiations. They will rely on the categories already provided to choose what to purchase, what to watch, what to protest, and what to invest in. The ratings system will come ready-made as a division of the programming umiverse, and the efficiency and ubiquity of the system will make its distmctions real in practice.

Just as parental groups today do not watch NC-17 movies before protesting their inclusion in suburban movie conplexes or local video stores, ${ }^{83}$ people will use the television ratings system

83. See, eg., Michael Granberry, 'Temptation': Some Resist, Others Yawn, L.A. TMES, Aug. 20, 1988, § 2, at 2; Julia McCord, Film on Fallen Priests Sparks Pastor Protest, OMAha World-Herald, Apr. 7, 1995, at 13SF; Sean P. Means, Pickets Organize to Protest 'Showgirls' in Utah: Kids' Movies and Skin Flicks a Bad Mix, Protesters Say, SALT LAKE TrIB., Sept. 28, 1995, at B1; Victor Volland, Video Stores Have 'Priest'; Groups Protest, ST. LouIS PosT-DisPaTCH, Jan. 27, 1996, at 5D. 
as a guide to the content of rated programming. The categories produced by a ratings board, whether public or private, will be the key informational filters that others will use to organize their decisions, whether monetary, pohtical, or aesthetic.

Nevertheless, it is possible that events will play out quite differently. If cable bandwidth is expanded-for example, through digital dehvery systems - there may be room for several different ratings systems. Groups like the Christian Coalition may offer their own ratings systein using V-chip technology, employing their own conception of what is family-friendly and what is not. Consumers can then subscribe to the ratings system of their choice, much as they now subscribe to magazines hike TV Guide. Moreover, an explosion of space on cable systems promises the possibility of filtering systems based on any number of programming criteria. The only limitation upon would-be filterers is their ability to catalogue and categorize the millions of hours of materials that will eventually exist for television, and their ability to gain sufficient market share to underwrite the costs of rating this material.

This possible future presents a different set of problems. On the one hand, if the number of ratings systeins that can survive commercially is quite small, the result will not be too dissimilar froin what I have described above. The inore interesting possibility is that ratings systems and related forms of media filters will proliferate. Consumers will be able to insulate themselves in increasingly specialized programming umiverses. By delegating their choices to specialized media filtermg companies, they can filter out the great mass of programming to focus narrowly on their own special interests. Some, I suspect, will see this as the ultimate vindication of autonomy. Others will mourn the loss of a common televisual culture. In any case, this scenario produces effects completely opposite of the first. Instead of a single filtering system uncannily structuring and skewing thought and culture, the alternative scenario imagines an increasingly fractured commumity of individuals fixated on their personal programming umiverse and increasingly oblivious to everything else.

Standing as we are, still in the infancy of the Information Age, it is impossible to tell how events will play out. But we can already appreciate the deep irony of our situation. The call for the $V$-chip, like the call for censorship of the Internet, stems from a sincerely felt anxiety that our culture is spinning out of control and an earnest desire to strike back at those new technologies 
thought to form part of the cause. The promotion of the V-chip as the solution to this cultural anxiety is at once appropriate and perverse. It is appropriate because it uses technology to fight the perceived effects of technology. It is perverse in that, like all other technologies before it, our submission to it is destimed to have immeasurable and unexpected consequences.

The inevitable emergence of filtering organizations, whether public or private, underscores the importance of distinguishing between delegation and choice-the distance between the informational future that awaits us and the attractive homilies of autonomy and personal empowerment now used to describe it. We are on the verge of installing a series of new filtering mechanisins that will transform the most important systems of inass communication available to us. We do this to satisfy the concerns of parents and the ambitions of politicians. But as we do this, we might be well advised to stop for a moment, and try to imagine what is as yet unimaginable-the profound though unintended effects of this potent combination of bureaucracy and technology on the health of our denocracy and the evolution of our culture. 
HeinOnline -- 45 Duke L.J. 1176 1995-1996 